\title{
Short-term spontaneous fluctuations of HBV DNA levels in a Senegalese population with chronic hepatitis B
}

Sarah Maylin 1,2*, Jean-Marie Sire ${ }^{3}$, Papa Saliou Mbaye ${ }^{4}$, François Simon ${ }^{1,2,5}$, Anna Sarr ${ }^{6}$, Marie-Louise Evra ${ }^{6}$, Fatou Fall ${ }^{4}$, Jean Daveiga ${ }^{7}$, Aboubakry Diallo ${ }^{8}$, Jean-Marc Debonne ${ }^{9}$, Loic Chartier ${ }^{10}$ and Muriel Vray ${ }^{10,11}$

\begin{abstract}
Background: We evaluated the short-term spontaneous fluctuations of HBV DNA and HBsAg levels in Senegalese patients with chronic infection with hepatitis B virus and normal ALT and determined factors related to these fluctuations.

Method: A total of 87 patients with persistent normal ALT values were enrolled in the study. Serum samples were obtained at three different visits, with an interval of 2 months (M0, M2, and M4), and without initiating anti HBV treatment. Levels of HBV DNA, quantitative HBsAg, ALT and AST, genotyping and viral DNA mutations were analyzed.

Results: Among the 87 patients, genotype E was predominant (75\%). The median HBV DNA level was $2.9 \log _{10}$ $\mathrm{IU} / \mathrm{mL}$ [2.2-3.4], $2.7 \log _{10} \mathrm{IU} / \mathrm{mL}$ [2.1-3.6] and $2.7 \log _{10} \mathrm{IU} / \mathrm{mL}$ [2.1-3.4] at M0, $\mathrm{M} 2$ and $\mathrm{M} 4$, respectively. The values ranged from $<1.1$ to $7 \log _{10} \mathrm{IU} / \mathrm{mL}$ and 55 (63\%) had HBV DNA fluctuations $\geq 0.5 \log _{10} \mathrm{IU} / \mathrm{mL}$ between two visits. Patients in whom HBV DNA fluctuated $\geq 0.5 \log _{10} \mathrm{IU} / \mathrm{mL}$ between $\mathrm{M0}$ and $\mathrm{M} 2$ also had significant fluctuations between $M 2$ and M4, while patients with stable HBV DNA between M0 and M2 showed a stable viral load between $\mathrm{M} 2$ and $\mathrm{M} 4$. The only factor found to be associated with HBV DNA fluctuations $\geq 0.5 \log _{10}$ $\mathrm{IU} / \mathrm{mL}$ was a low BMI $\left(<21 \mathrm{~kg} / \mathrm{m}^{2}\right)$. HBsAg levels were not correlated with HBV DNA levels.

Conclusion: Sixty-three percent of the enrolled Senegalese population showed a large, short-term fluctuation of HBV DNA levels. Such fluctuations may have an impact on therapeutic management, requiring closer monitoring.
\end{abstract}

Keywords: HBV DNA level, HBsAg quantification, Short-term spontaneous fluctuation, Chronic Hepatitis B

\section{Background}

Hepatitis B virus (HBV) infection is a global epidemic, with more than 350 million of chronically infected carriers of the virus surface antigen (HBsAg) [1]. Without treatment, 15 to $40 \%$ of those with chronic HBV infection will develop cirrhosis that can potentially lead to hepatocellular carcinoma [2].

HBV is hyperendemic in Senegal, where the prevalence of chronic HBsAg carriage is about $15-20 \%$ in the

\footnotetext{
*Correspondence: sarah.maylin@sls.aphp.fr

'Laboratoire de Virologie, Hôpital Saint-Louis, AP-HP, 1 avenue Claude Vellefaux, Paris, France

2Université Paris-Diderot, Paris, France

Full list of author information is available at the end of the article
}

general population [3]. Senegalese patients are primarily infected during early childhood, and genotypes $\mathrm{E}$ and A predominate in these infections. HBV infection in Senegal shows an $83 \%$ rate of precore mutations [4]. Reliable, easy-to-perform markers are needed to assess the impact of chronic HBV infection on liver diseases. Quantification of plasma HBV DNA by real-time PCR, combined with liver biopsy histo-pathological stage and biological markers of hepatocyte cytolysis level, can distinguish inactive $\mathrm{HBsAg}$ carriers from patients with active disease who require treatment. Patients should be considered for treatment when they have HBV DNA levels above $2000 \mathrm{IU} / \mathrm{mL}\left(3.2 \log _{10} \mathrm{IU} / \mathrm{mL}\right)$, or serum alanine aminotransferase (ALT) levels above the upper 
limit of normal (ULN) and liver biopsy suggestive of significant fibrosis $(\geq \mathrm{F} 2)[5]$. In developing countries, viral load measurement is rarely accessible. If only one measure of viral load is available, it may not reflect real viral activity. Possible fluctuations may affect the indication of treatment. However, several studies have shown longterm HBV DNA spontaneous fluctuations [6,7]. The magnitude of these changes is likely to change a treatment decision [7]. Short-term fluctuations and factors affecting them remain unknown [8].

Recently, HBsAg levels have been proposed as a marker for monitoring HBV infected patients $[9,10]$. HBsAg levels change over the natural course of chronic HBV infection and during antiviral therapy. Moreover, HBsAg quantification can be used to differentiate true inactive carriers with HBsAg level $<1000 \mathrm{IU} / \mathrm{mL}$ from patients in remission who are likely to progress to cirrhosis [11]. The aim of this work is to describe spontaneous HBV DNA and HBsAg level fluctuations over a four month- follow-up period among Senegalese patients positive for HBsAg with normal ALT, so as to identify factors associated with these fluctuations.

\section{Methods}

\section{Patient population}

Patients were consecutively enrolled by private practitioners and by four public hospitals in Dakar, Senegal's capital city, from September 2005 to April 2006. Treatment-naive patients above 18 years old, with positive HBsAg over six months, symptom-free, HIV, HCV and HDV negative, were eligible for enrolment.

Eighty-seven patients with persistent normal ALT values were prospectively monitored for determination of ALT and aspartate aminotransferase (AST), quantification of HBV DNA three times at two-month intervals (M0, M2, and M4). For those with positive HBV DNA, genotyping and mutations affecting the expression of HBeAg were performed.

\section{Ethical approvals}

The protocol was in accordance with Declaration of Helsinki ethical guidelines and was approved by the Senegalese Health Research National Council. Patients fulfilling the inclusion criteria were enrolled after providing written and informed consent. Lamivudine was proposed to patients eligible for treatment, according to the above mentioned criteria.

\section{Material and methods Data collection}

The following data were collected [1]: general characteristics (age, sex, weight, height, known HBV infection duration, body mass index (BMI)) [2]; biological markers at the inclusion (genotype, $\mathrm{HBeAg}, \mathrm{HBsAg}$ and platelets).
HBV DNA, HBsAg quantification, ALT, AST, were measured three times with intervals of two months (M0, M2 and M4). ALT and AST results were expressed relative to the normal values according to the technique used (Ortho Clinical Diagnostics, Issy-les-Moulineaux, France) i.e. $52 \mathrm{IU} / \mathrm{mL}$ (females) and $72 \mathrm{IU} / \mathrm{mL}$ (males) for ALT, and $36 \mathrm{IU} / \mathrm{mL}$ (females) and $59 \mathrm{IU} / \mathrm{mL}$ (males) for AST. Variations of ALT, AST, HBsAg and HBV DNA between two visits were determined and expressed as $\triangle \mathrm{ALT}, \triangle \mathrm{AST}, \triangle \mathrm{HBsAg}$ and $\triangle \mathrm{HBV}$ DNA, respectively.

\section{Biological markers}

$\mathrm{HBeAg}$ and qualitative HBsAg were performed by an automated EIA method (Axsym, Abbott Diagnostics, Rungis, France). Biochemical parameters were determined by Vitros 250 instrument (Ortho Clinical Diagnostics, Issyles-Moulineaux, France). Platelets were determined by Cell-Dyn 3700 (Abbott).

\section{Virological analyses}

The HBV DNA quantification was performed using the Cobas AmpliPrep/Cobas Taqman HBV test, v1.0 assay (Roche Diagnostics, Meylan, France), with a detection threshold of $12 \mathrm{IU} / \mathrm{mL}\left(1.1 \log _{10} \mathrm{IU} / \mathrm{mL}\right)$.

The core mutation W28 at nucleotide 1896 (precore mutation C28) and clade genotyping were determined by research DNA microarray (bioMérieux, Marcy l'Etoile, France) [12].

\section{HBsAg quantification}

Serum HBsAg levels were retrospectively quantified using sera stored at $-20{ }^{\circ} \mathrm{C}$, which had been used for HBV DNA measurement. Architect HBsAg EIA (Abbott, Rungis, France) [13] was used with a dynamic range of $0.05-250 \mathrm{IU} / \mathrm{mL}$. Samples with HBsAg $>250 \mathrm{IU} / \mathrm{mL}$ were diluted to $1 / 100$ to bring the value within the range of calibration [14].

\section{Statistical analysis}

Continuous variables were expressed as median and interquartile ranges (IQR), and categorical variables were expressed as percentages. Univariate analyses were based on Fisher's exact test for categorical variables and Mann-Whitney test for continuous variables. The HBsAg $\left(\log _{10} \mathrm{IU} / \mathrm{mL}\right)$ to HBV DNA $\left(\log _{10} \mathrm{IU} / \mathrm{mL}\right)$ ratio was assessed for all serum samples according to HBV DNA levels $(\leq 3] 3-4],] 4-5]$, and $\left.>5 \log _{10} \mathrm{IU} / \mathrm{mL}\right)$. Comparison of ratios between levels of HBV replication was analyzed with the Kruskal-Wallis non-parametric test. When a significant difference was detected, MannWhitney test was performed, with Bonferroni correction for multiple testing. HBsAg and HBV DNA fluctuations were measured three times at two month intervals (M0, M2 and M4). For each subject, the largest difference in 
HBV DNA levels between two consecutive visits was recorded and classified according to four classes: $\leq 0.5$,] $0.5-1][] 1-2$,$] and >2 \log _{10} \mathrm{IU} / \mathrm{mL}$. Friedman's test was used to compare HBsAg fluctuations between the three values. Correlation between viral load fluctuations was based on the Spearman coefficient.

All variables associated with $\mathrm{HBV}$ DNA fluctuations $>0.5$ $\log _{10} \mathrm{IU} / \mathrm{mL}$ in univariate analysis $(\mathrm{p}<0.25)$ were included in a backward stepwise logistic regression model. A $P$ value of $\leq 0.05$ was considered to denote statistical significance. Statistical analyses were performed using STATA software version 12.0 (Stata Corporation, College Station, TX).

\section{Results}

Population characteristics

The characteristics of the studied population are summarized in Table 1 . The population was primarily male (72\%), with a median age of 30 years and a median BMI of $21 \mathrm{~kg} / \mathrm{m}^{2}$. All patients maintained normal ALT, with a median of $0.5 x U L N$ (upper limit of normal) [0.4-0.6] over the three visits. Genotype E was predominant (75\%), the remaining belonging to genotype $\mathrm{A}$. The median $\mathrm{HBV}$ DNA level was 2.9, 2.7 and $2.7 \log _{10} \mathrm{IU} / \mathrm{mL}$ for the first, second and third visits, respectively (Table 2 ). The values ranged between $<1.1$ (undetectable) and $7 \log _{10} \mathrm{IU} / \mathrm{mL}$. Thirty-six subjects (41\%) had at least one visit with a viral load $\geq 3.2 \log _{10} \mathrm{IU} / \mathrm{mL}$. Only 15 patients $(17 \%)$ were above $\geq 3.2 \log _{10} \mathrm{IU} / \mathrm{mL}$ and five patients $(6 \%)$ had an undetectable HBV DNA $\left(<1.1 \log _{10} \mathrm{IU} / \mathrm{mL}\right)$ throughout the three visits.

Ninety percent of patients had a detectable viral load at baseline (M0) and among them, two patients (5\%) had a positive HBeAg. Ninety four percent of patients had at least one visit with detectable viral load, while $6 \%$ were always undetectable $(<1.1 \log )$ over all the visits.

\section{Table 1 Characteristics of the 87 subjects}

\begin{tabular}{lll}
\hline Variables & $\mathbf{N}(\%)$ & Median [IQR] \\
\hline Age (years) & & $30[25-38]$ \\
Gender (males) & $63(72)$ & \\
BMI $\left(\mathrm{kg} / \mathrm{m}^{2}\right)$ & & $21[19-24]$ \\
- ALT $\left(X \cup L N^{*}\right)$ & $0.5[0.4-0.6]$ \\
- AST (XULN*) & $0.5[0.4-0.7]$ \\
Platelets (giga/L) & $194[163-245]$ \\
Precore (W28) mutation $\mathbf{( n = 6 2 )}$ & & \\
- Wild type & $35(56)$ & \\
- Mutation & $27(44)$ & \\
HBV Genotype $(\mathbf{n}=\mathbf{6 3})$ & & \\
- A & $16(25)$ & \\
- E & $47(75)$ & \\
\hline
\end{tabular}

*ULN: upper limit of normal.
Table 2 HBsAg and HBV DNA levels in the 87 subjects at M0, M2 and M4

\begin{tabular}{|c|c|c|}
\hline Variables & $N(\%)$ & Median [IQR] \\
\hline \multicolumn{3}{|l|}{ HBV-DNA $\log _{10} 1 \mathrm{U} / \mathrm{mL}$} \\
\hline - First sample & & $2.9[2.2-3.4]$ \\
\hline - Second sample & & $2.7[2.1-3.6]$ \\
\hline - Third sample & & $2.7[2.1-3.4]$ \\
\hline \multicolumn{3}{|c|}{$\triangle \mathrm{HBV}$-DNA $\log _{10}$ between 2 visits } \\
\hline$-\leq 0.5$ & $32(37)$ & \\
\hline-$] 0.5-1]$ & $31(36)$ & \\
\hline-$] 1-2]$ & $16(18)$ & \\
\hline$->2$ & $8(9)$ & \\
\hline \multicolumn{3}{|l|}{ HBV-DNA $\log _{10}$} \\
\hline - $<3.2 \log _{10}$ for all the visits & $36(41)$ & \\
\hline - $\geq 3.2 \log _{10}$ for 1 or 2 visits & $36(41)$ & \\
\hline - $\geq 3.2 \log _{10}$ for all the visits & $15(17)$ & \\
\hline \multicolumn{3}{|l|}{$\mathrm{HBsAg} I U / \mathrm{mL}$} \\
\hline - First sample & & 4672 [1473-8355] \\
\hline - Second sample & & 4546 [1749-8871] \\
\hline - Third sample & & 3473 [1241-8765] \\
\hline
\end{tabular}

\section{Viral load fluctuations}

Sixty-three percent of subjects $(n=55)$ experienced a change in viral load of at least $0.5 \log _{10} \mathrm{IU} / \mathrm{mL}$ between two visits. In 8 patients (9\%) the difference was $>2 \log _{10}$ $\mathrm{IU} / \mathrm{mL}\left(\max 2.8 \log _{10}\right.$ of difference) (Table 2). Intraindividual changes over time in viral load based on fluctuation ranges are represented in the figures as spaghetti plots (Figures 1 and 2).

The only factor associated with a change in the viral load $>0.5 \log$ was $\mathrm{BMI}<21 \mathrm{~kg} / \mathrm{m}^{2}$ (OR: $3.5 ; 95 \% \mathrm{CI}$, 1.3-9.0) (Table 3).

Patients in whom HBV DNA fluctuated $>0.5 \log _{10}$ $\mathrm{IU} / \mathrm{mL}$ between M0 and M2 also showed significant fluctuation between M2 and M4 (positive correlation $\mathrm{r}=0.34, \mathrm{p}=0.005$ ) (Figure 3), while patients with stable HBV DNA between M0 and M2 showed a stable viral load between M2 and M4 (Figure 4). Such significant fluctuations were only observed in patients with genotype $\mathrm{E}$ viruses (positive correlation $\mathrm{r}=0.42, \mathrm{p}=0.05$ ). For $45 \%$ of the patients, the largest variation observed between two samples was between the second and third samples.

\section{HBsAg fluctuations}

The values of HBsAg differed significantly between the three visits $(\mathrm{p}=0.03)$, mainly due to the difference observed between the second and third samples, with respective medians of 4546 and $3473 \mathrm{IU} / \mathrm{mL}$ (Table 2).

We did not find a link between HBsAg fluctuations and a change in the viral load $>0.5 \log _{10} \mathrm{IU} / \mathrm{mL}$ (Table 3 ). There is no significant difference in HBsAg levels, 


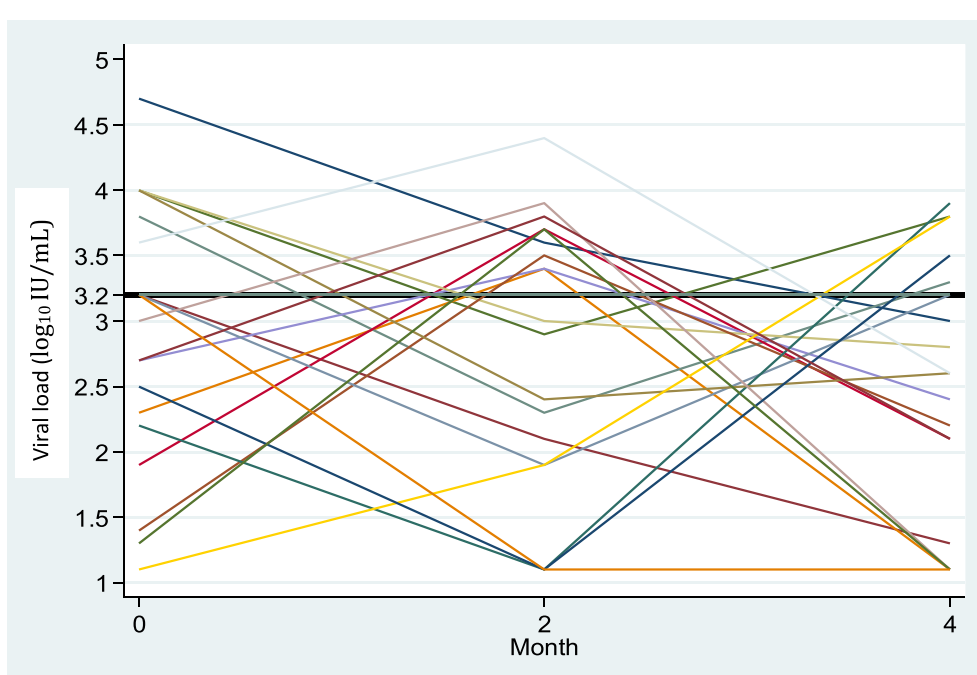

Figure 1 Viral load fluctuations between M0 and M4 in patients with a change in viral load $\left.\geq 1 \log { }_{10} \mathrm{lU} / \mathrm{mL}(\mathrm{n}=19)\right)(\mathrm{x}$ axis $=$ months; y axis $=$ viral load fluctuations $\left(\log _{10} \mathrm{IU} / \mathrm{ml}\right)$.

regardless of the genotype (A/E) or the presence of a precore mutation C28 (Table 4). The median HBsAg level in patients with $\mathrm{HBeAg}$ negative was 6612 [18799260], 6228 [1905-9089) and 5393 [2269-9883] IU/mL for the first, second and third samples, respectively. The HBsAg level was 7584 and $8765 \mathrm{IU} / \mathrm{mL}$ for the second and third samples for the sole patient with positive HBeAg.

\section{HBsAg/HBV DNA ratio}

The median HBsAg $\left(\log _{10} \mathrm{IU} / \mathrm{mL}\right)$ to HBV DNA $\left(\log _{10}\right.$ $\mathrm{IU} / \mathrm{mL}$ ) ratio was significantly higher in samples with
HBV DNA values $\leq 3 \quad \log _{10} \mathrm{IU} / \mathrm{mL}(1.48$ [1.24-1.73]), compared to high HBV DNA values (1.04 [0.91-1.15] for]3-4] $\log _{10} \mathrm{IU} / \mathrm{mL}$ ( $\left.\mathrm{p}<0.001\right)$, 0.94 [0.67-0.95] for]4-5] $\log _{10} \mathrm{IU} / \mathrm{mL}(\mathrm{p}=0.05)$ and 0.63 [0.58-0.67] for more than $\left.5 \log _{10} \mathrm{IU} / \mathrm{mL},(\mathrm{p}<0.001)\right)$ (Figure 5).

\section{Discussion}

This study highlights the frequency and magnitude of spontaneous HBV DNA fluctuations over a short period (4 months) among Senegalese patients with normal transaminases, as well as their possible impact on clinical characterization of the disease and its therapeutic

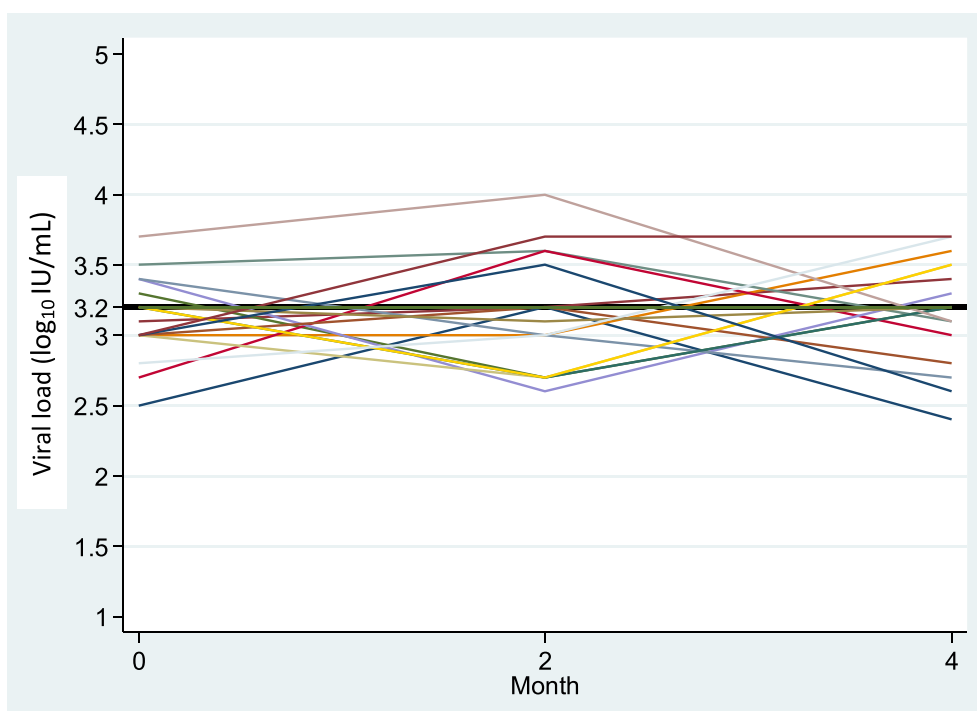

Figure 2 Viral load fluctuations between M0 and M4 in patients with a change in viral load $<1 \log _{10} \mathrm{IU} / \mathrm{mL}(\mathrm{n}=17)(\mathrm{x}$ axis $=$ months; y axis $=$ viral load fluctuations with a change $<1 \log _{10} \mathrm{IU} / \mathrm{ml}$ ). 
Table 3 Factors associated with fluctuation of HBV DNA greater than $0.5 \log _{10} \mathrm{IU} / \mathrm{mL}$

\begin{tabular}{|c|c|c|c|}
\hline \multirow[t]{2}{*}{ Variables - N (\%) } & \multicolumn{2}{|c|}{ Patients with a change in viral load between two samples } & \multirow[t]{2}{*}{ p value } \\
\hline & $\leq 0.5 \log _{10} \mathrm{IU} / \mathrm{mL}(\mathrm{n}=32)$ & $>0.5 \log _{10} \mathrm{IU} / \mathrm{mL}(\mathrm{n}=55)$ & \\
\hline Gender (males) & $23(72)$ & $40(73)$ & 0.93 \\
\hline Age $\geq 30$ yrs & $22(69)$ & $26(47)$ & 0.052 \\
\hline $\mathrm{BMI}<21\left(\mathrm{~kg} / \mathrm{m}^{2}\right)$ & $10(31)$ & $32(62)$ & 0.007 \\
\hline Platelets (giga/L)* & $188[168-214]$ & 209 [161-247] & 0.94 \\
\hline$\triangle \mathrm{ALT}^{*}$ & $3[1-8]$ & $5[3-9]$ & 0.19 \\
\hline$\triangle \mathrm{AST}^{*}$ & $2[1-6]$ & $4[2-7]$ & 0.075 \\
\hline$\triangle \mathrm{HBsAg}^{*}(\mathrm{n}=51)$ & 924 [355-1248] & 627 [218-1479] & 0.99 \\
\hline Genotype $E(n=63)$ & $15(79)$ & $32(73)$ & 0.60 \\
\hline \multicolumn{4}{|c|}{ Precore mutation C28 $(n=62)$} \\
\hline - Wild type & $9(50)$ & $16(36)$ & \multirow[t]{2}{*}{0.32} \\
\hline - Mutation & $9(50)$ & $28(64)$ & \\
\hline
\end{tabular}

*median [IQR].

management. The lack of association between these fluctuations and demographic parameters (age, gender) or biochemical (transaminases) or virological data (genotype, mutations affecting the expression of $\mathrm{HBeAg}$ ) could be explained by a lack of power because of the small number of subjects included in the study. Low BMI $<21 \mathrm{~kg} / \mathrm{m}^{2}$ was the only factor associated with HBV DNA fluctuations; patients with a lower BMI values were at higher risk of having fluctuations. One hypothesis is that HBV DNA fluctuations can reflect more efficient immune response which is more present in healthy, low BMI patients. As previously demonstrated, there is strong evidence that excess adiposity, defined by high BMI, negatively impacts immune function and host defenses in obese individuals [15].

The stability of the biochemical markers contrasts with the volatility of the HBV DNA.

The lower replicativity among $\mathrm{HBeAg}$ negative patients does not explain the HBV DNA variability observed in our study.

The frequency and magnitude of DNA fluctuations and their possible impact on clinical characterization of the disease and its therapeutic management must be emphasized. Guidelines recommend that to be eligible for treatment, patients must have a viral load greater than or equal to HBV DNA $3.2 \log \mathrm{IU} / \mathrm{mL}$. Only $17 \%$ of our

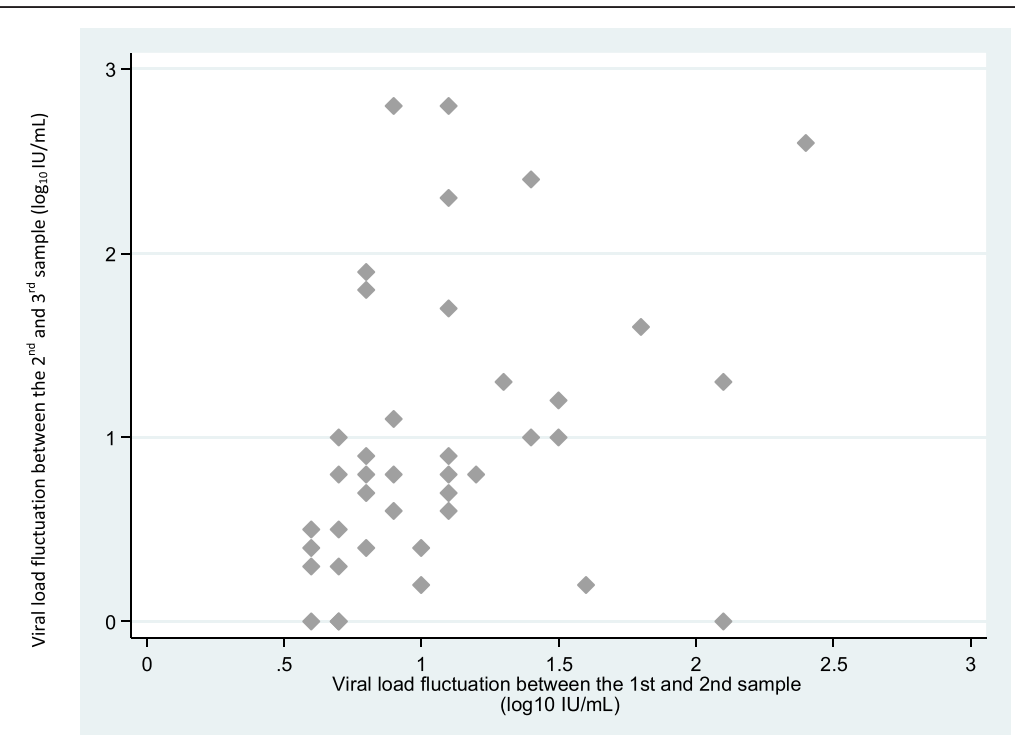

Figure 3 Viral load fluctuation $\left(\log _{10} \mathrm{IU} / \mathrm{mL}\right.$ ) between the second and third samples in patients for whom viral load fluctuation between the first and second sample was $>0.5 \log _{10} \mathrm{IU} / \mathrm{mL}$ ( $x$ axis = viral load fluctuations between the first and second sample (M0 et M2) $\left(\log _{10} \mathrm{IU} / \mathrm{mL}\right) ; y$ axis = viral load fluctuations between the second and third sample (M2 et M4) $\left(\log _{10} \mathrm{IU} / \mathrm{mL}\right)$. 


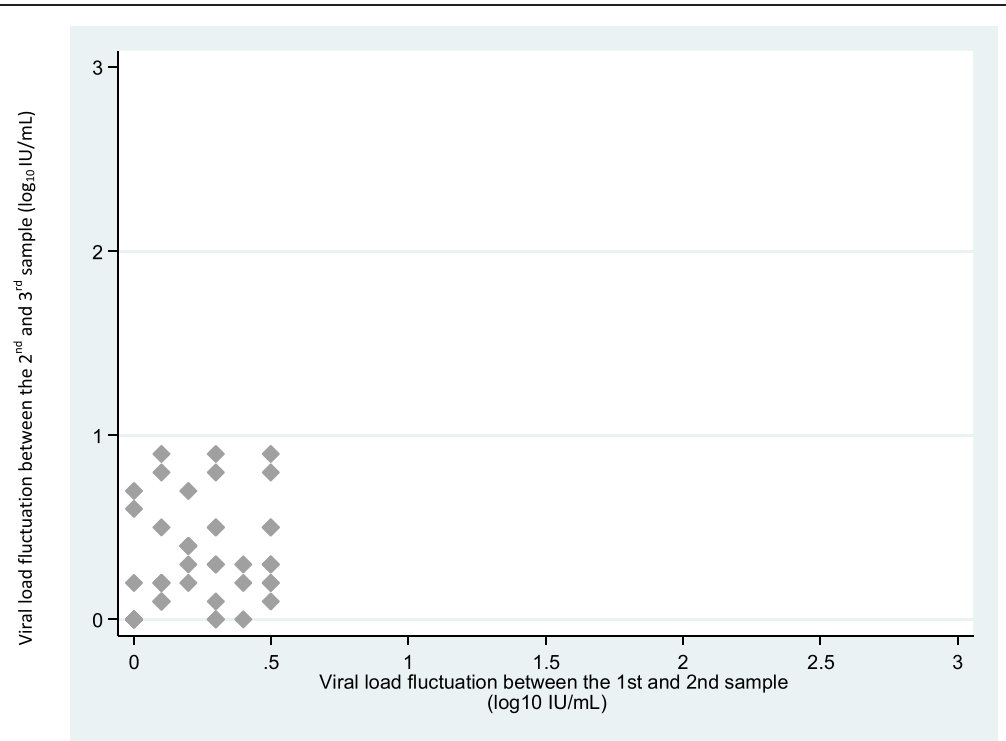

Figure 4 Viral load fluctuation between the second and third samples in patients for whom viral load fluctuation between the first and second sample was $\leq 0.5 \log _{10} \mathrm{IU} / \mathrm{mL}$. ( $\mathrm{x}$ axis = viral load fluctuations between the first and second sample (M0 et M2) (log $\left.10 \mathrm{IU} / \mathrm{mL}\right) ; \mathrm{y}$ axis $=$ viral load fluctuations between the second and third sample (M2 et M4) $\left(\log _{10} \mathrm{IU} / \mathrm{mL}\right)$.

patients constantly exceeded this threshold in the three samples tested (M0, M2 and M4). Forty-two percent of patients would have been eligible or ineligible for treatment according to the viral load value at a given time. It therefore seems necessary to measure viral load for multiple occasions before deciding to treat.

More recently, studies have reported that the management of chronic hepatitis B can be optimized with HBsAg quantification, used as a biomarker for stratifying the risk of disease progression [16] and for predicting treatment response mainly in patients receiving pegylated interferon (PEG-IFN) therapy [17].

In clinical practice, HBsAg quantification cannot replace viral load measurement. Combining both measures has been shown to be important for monitoring the natural history of the disease and treatment outcome [11]. We observed a significant reduction in the HBsAg level between the second and third visits. Consistent with other studies, we found no correlation between HBV DNA levels and HBsAg in these HBeAg-negative patients [18]. It has been shown that the HBsAg / HBV DNA ratio, which reflects the association between HBsAg production and HBV replication, increased after seroconversion without any HBsAg level modification. Confirming immune control over viral replication was the first step of immune clearance. This ratio has been shown to be higher during the low-replicative phase, compared to immune-tolerant, immune-clearance and $\mathrm{HBeAg}$ negative hepatitis phase and to be repeatable regardless to ethnicity or genotype [19-21]. Nevertheless, in our study, the HBsAg / HBV DNA ratio was higher in samples with low HBV DNA values than in those with high HBV DNA values, as reported by others [22]. These results suggest that the production of $\mathrm{HBsAg}$ is more conserved than the HBV DNA replication indicating that the association between HBsAg production and HBV DNA replication seems disconnected $[23,24]$.

Table 4 Fluctuations of HBsAg levels

\begin{tabular}{|c|c|c|c|c|c|c|}
\hline Variables - Median (IQR) & $\begin{array}{l}\text { HBsAg levels* } \\
\text { (1 } 1^{\text {st }} \text { sample) }\end{array}$ & $\mathbf{p}$ & $\begin{array}{l}\text { HBsAg levels* } \\
\left(2^{\text {nd }} \text { sample }\right)\end{array}$ & $\mathrm{p}$ & $\begin{array}{l}\text { HBsAg levels* } \\
\text { ( } 3^{\text {rd }} \text { sample) }\end{array}$ & p \\
\hline Genotype $(n=43)$ & & 0.37 & & 0.30 & & 0.33 \\
\hline$-E$ & $5648(1914-10404)$ & & $5545(2571-9876)$ & & $4486(2611-9624)$ & \\
\hline$-A$ & $6429(618-9134)$ & & $6228(635-8871)$ & & $4943(610-9896)$ & \\
\hline Precore mutation C28 in negative $\mathrm{HBeAg}$ patients & & 0.26 & & 0.56 & & 0.56 \\
\hline Wild type $(n=13)$ & $7058(1473-8355)$ & & $6228(1556-8871)$ & & $4943(1241-9883)$ & \\
\hline Mutation $+(n=14)$ & $6906(2964-12711)$ & & $7954(3170-10389)$ & & $6874(2952-10703)$ & \\
\hline
\end{tabular}

*IU/mL. 


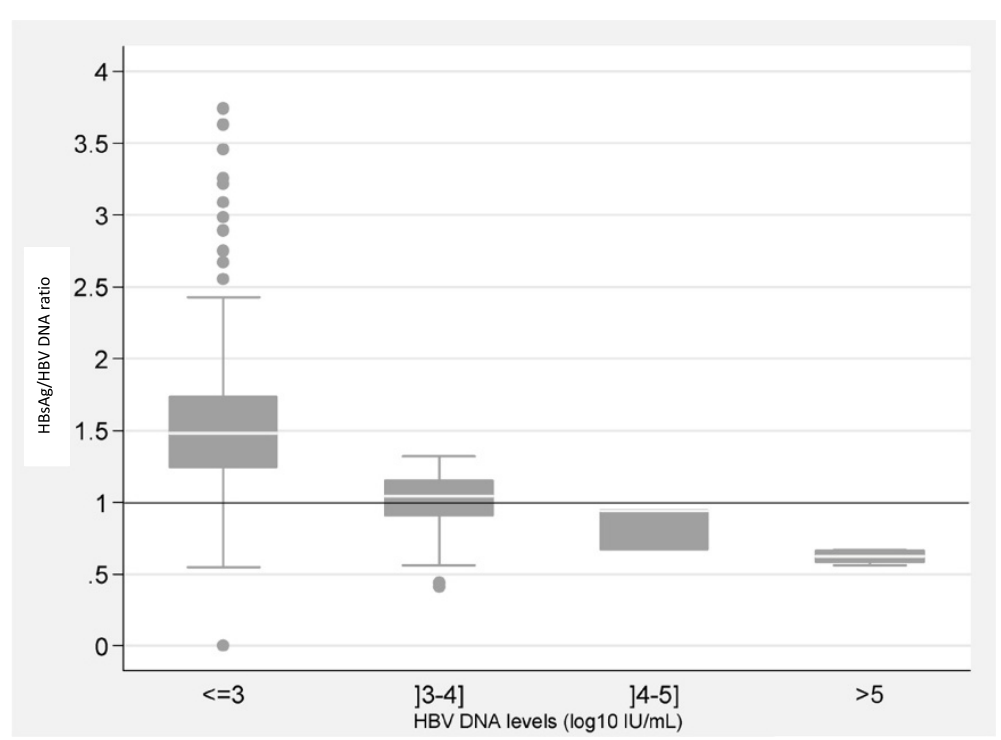

Figure 5 Plots of $\log _{10} \mathrm{IU} / \mathrm{ml} \mathrm{HBsAg} / \mathrm{HBV}$-DNA ratio by levels of HBV replication. (all samples) (x axis = BV DNA levels (log $\left.10 \mathrm{IU} / \mathrm{mL}\right)$; y axis $=$ HBsAg /HBV-DNA ratio).

\section{Conclusion}

Since HBeAg-negative patients with higher HBsAg levels were more susceptible to developing active disease, quantification of HBsAg in such patients merits further investigation.

\section{Competing interests}

The authors declare that they have no competing interests.

\section{Authors' contribution}

All authors read and approved the final version of the manuscript. Conceived and designed the experiments: MV, FS, PSM. Recruited and collected clinical data: AS, MLE, FF, JD, AD, JMD. Performed the experiments: JMS, SM. Analyzed the data: LC, SM, JMS, FS, MV. Drafted the manuscript: LC, SM, JMS, FS, MV. Revised the manuscript: LC, SM, JMS, FS, MV, AS, MLE, FF, $J D, A D, J M D, P S M$.

\section{Acknowledgements}

We thank Tamara Giles-Vernick for reading the manuscript and the reviewers to improve the manuscript.

Finally, the authors are also grateful to the patients and clinical teams for their commitment to the protocol Study.

\section{Financial support}

The ANRS (National Institute of Research on AIDS and Viral Hepatitis) funded this study. The funders had no role in study design, data collection and analysis, decision to publish, or preparation of the manuscript.

\section{Author details}

'Laboratoire de Virologie, Hôpital Saint-Louis, AP-HP, 1 avenue Claude Vellefaux, Paris, France. 2Université Paris-Diderot, Paris, France. ${ }^{3}$ Laboratoire de Microbiologie, Centre hospitalier intercommunal de Poissy-Saint-Germain-en-Laye, Poissy, France. ${ }^{4}$ Department of Hepatology and Gastroenterology, Principal Hospital, Dakar, Senegal. ${ }^{5}$ Inserm U941, Paris, France. ${ }^{6}$ Department of Hepatology and Gastroenterology, Abass Ndao Hospital, Dakar, Senegal. 'Department of Hepatology and Gastroenterology, Saint-Jean de Dieu Hospital, Thies, Senegal. ${ }^{8}$ Department of Hepatology and Gastroenterology, Grand-Yoff Hospital, Dakar, Senegal. ${ }^{9}$ Direction des Services de Santé des Armées, Paris, France. ${ }^{10}$ Epidemiology Unit of Infectious Diseases, Institut Pasteur, 25 rue du Dr Roux, Paris 75015, France. ${ }^{11}$ INSERM, Paris, France.
Received: 30 December 2014 Accepted: 12 March 2015

Published online: 25 March 2015

\section{References}

1. Lavanchy D. Hepatitis B, virus epidemiology, disease burden, treatment, and current and emerging prevention and control measures. J Viral Hepat. 2004;11(2):97-107.

2. McMahon BJ. Natural history of chronic hepatitis B - clinical implications. Medscape J Med. 2008;10(4):91.

3. Etard J-FColbachini P, Dromigny JA, Perrier-Gros-Claude JD. Hepatitis C antibodies among blood donors, Senegal, 2001. Emerg Infect Dis. 2003;9(11):1492-3.

4. Vray M, Debonne JM, Sire JM, Tran N, Chevalier B, Plantier JC, et al. Molecular epidemiology of hepatitis B virus in Dakar, Sénégal. J Med Virol. 2006;78(3):329-34.

5. European Association For The Study Of The Liver. EASL clinical practice guidelines: Management of chronic hepatitis B virus infection. J Hepatol Juill. 2012;57(1):167-85.

6. Kwon H, Lok AS. Hepatitis B therapy. Nat Rev Gastroenterol Hepatol. 2011;8(5):275-84.

7. Papatheodoridis GV, Chrysanthos N, Hadziyannis E, Cholongitas E, Manesis EK. Longitudinal changes in serum HBV DNA levels and predictors of progression during the natural course of HBeAg-negative chronic hepatitis B virus infection. J Viral Hepat. 2008;15(6):434-41.

8. Chun YK, Kim JY, Woo HJ, Oh SM, Kang I, Ha J, et al. No significant correlation exists between core promoter mutations, viral replication, and liver damage in chronic hepatitis B infection. Hepatology. 2000;32(5):1154-62.

9. Thompson AJ, Nguyen T, Iser D, Ayres A, Jackson K, Littlejohn M, et al. Serum hepatitis $B$ surface antigen and hepatitis $B$ e antigen titers: disease phase influences correlation with viral load and intrahepatic hepatitis B virus markers. Hepatology. 2010;51(6):1933-44.

10. Chan HL, Wong WW, Wong GL, Tse CH, Chan HY, Sung JJ. A longitudinal study on the natural history of serum hepatitis B surface antigen changes in chronic hepatitis B. Hepatology. 2010;52(4):1232-41.

11. Martinot-Peignoux M, Lapalus M, Asselah T, Marcellin P. The role of HBsAg quantification for monitoring natural history and treatment outcome. Liver Int Févr. 2013;33 Suppl 1:125-32.

12. Gauthier M, Bonnaud B, Arsac M, Lavocat F, Maisetti J, Kay A, et al. Microarray for hepatitis B virus genotyping and detection of 994 mutations along the genome. J Clin Microbiol. 2010;48(11):4207-15. 
13. Deguchi M, Yamashita N, Kagita M, Asari S, Iwatani Y, Tsuchida T, et al. Quantitation of hepatitis B surface antigen by an automated chemiluminescent microparticle immunoassay. J Virol Methods. 2004;115(2):217-22.

14. Moucari R, Mackiewicz V, Lada O, Ripault MP, Castelnau C, Martinot-Peignoux $M$, et al. Early serum HBsAg drop: a strong predictor of sustained virological response to pegylated interferon alfa-2a in HBeAg-negative patients. Hepatology. 2009;49(4):1151-7.

15. Milner JJ, Beck MA. The impact of obesity on the immune response to infection. Proc Nutr Soc. 2012;71(2):298-306.

16. Tseng TC, Liu CJ, Yang HC, Su TH, Wang CC, Chen CL, et al. Serum hepatitis B surface antigen levels help predict disease progression in patients with low hepatitis B virus loads. Hepatology. 2013;57(2):441-50.

17. Martinot-Peignoux M, Asselah T, Marcellin P. HBsAg quantification to predict natural history and treatment outcome in chronic hepatitis B patients. Clin Liver Dis. 2013;17(3):399-412.

18. Chan HL, Wong WW, Tse AM, Tse CH, Chim AM, Chan HY, et al. Serum hepatitis $B$ surface antigen quantitation can reflect hepatitis $B$ virus in the liver and predict treatment response. Clin Gastroenterol Hepatol. 2007:5(12):1462-8.

19. Nguyen T, Thompson AJ, Bowden S, Croagh C, Bell S, Desmond PV, et al Hepatitis B surface antigen levels during the natural history of chronic hepatitis B: a perspective on Asia. J Hepatol. 2010;52:508-13.

20. Jaroszewicz J, Calle Serrano B, Serrano B, Wursthorn K, Deterding K, Schlue J, et al. Hepatitis $B$ surface antigen (HBsAg) levels in the natural history of hepatitis B virus (HBV)-infection: a European perspective. J Hepatol. 2010;52:514-22.

21. Song JC, Min BY, Kim JW, Kim JY, Kim YM, Shin CM, et al. Pretreatment serum HBsAg-to-HBV DNA ratio predicts a virologic response to entecavir in chronic hepatitis B. Korean J Hepatol. 2011;17(4):268-73. doi:10.3350/ kjhep.2011.17.4.268.

22. Tuaillon E, Mondain AM, Nagot N, Ottomani L, Kania D, Nogue E, et al. Comparison of serum HBsAg quantitation by four immunoassays, and relationships of $\mathrm{HBsAg}$ level with $\mathrm{HBV}$ replication and HBV genotypes. PLoS One. 2012;7(3):e32143.

23. Neumann AU, Phillips S, Levine I, ljaz S, Dahari H, Eren R, et al. Novel mechanism of antibodies to hepatitis $b$ virus in blocking viral particle release from cells. Hepatology. 2010;52(3):875-85.

24. Neumann AU. Hepatitis B, viral kinetics: a dynamic puzzle still to be resolved. Hepatology. 2005;42(2):249-54.

\section{Submit your next manuscript to BioMed Central and take full advantage of:}

- Convenient online submission

- Thorough peer review

- No space constraints or color figure charges

- Immediate publication on acceptance

- Inclusion in PubMed, CAS, Scopus and Google Scholar

- Research which is freely available for redistribution 